\title{
Hubungan Perilaku Pemberantasan Sarang Nyamuk dan Kejadian Demam Berdarah Dengue di Kota Bandar Lampung
}

\author{
Amrul Hasan* Dian Ayubi**
}

\begin{abstract}
Abstrak
Kasus demam berdarah dengue di Kota Bandar Lampung terus mengalami peningkatan. Pada tahun 2001 incidence rate sebesar 13,56 per 100.000 penduduk, meningkat menjadi 109,8/100.000 penduduk pada tahun 2006 dan akhir Februari 2007 Kota Bandar Lampung dinyatakan Kejadian Luar Biasa (KLB) Demam berdarah dengue lokal. Penelitian ini bertujuan mengetahui hubungan kebiasaan melakukan pemberantasan sarang nyamuk (PSN) dengan kejadian demam berdarah dengue di Kota Bandar Lampung. Penelitian ini menggunakan desain kasus kontrol dengan jumlah sampel sebanyak 406 individu terdiri dari 203 kasus dan 203 kontrol. Kasus adalah individu yang menderita DBD yang pernah dirawat di rumah sakit dan dilaporkan ke Dinas Kesehatan Kota Bandar Lampung dari tanggal 1 Maret 2007 sampai 15 Mei 2007, sedangkan kontrol dipilih dari tetangga kasus yang bertempat tinggal dalam radius 100 meter dari tempat tinggal kasus. Penelitian ini menemukan bahwa ada hubungan kebiasaan melakukan PSN dengan kejadian demam berdarah dengue, individu yang tidak melakukan PSN berisiko 5,85 kali terkena DBD dibandingkan dengan individu yang melakukan PSN setelah variabel riwayat tetangga yang pernah sakit DBD, keberadaan benda yang dapat penampung air di sekitar rumah dan kebiasaan melakukan pencegahan gigitan nyamuk dikendalikan. Petugas puskesmas agar melaksanakan kegiatan Penyelidikan Epidemiologi dalam menanggulangi demam berdarah lebih memfokuskan kepada penggerakan masyarakat.
\end{abstract}

Kata kunci : DBD, Aedes aegypti, Pencegahan gigitan nyamuk

\section{Abstract}

Dengue hemorrhagic fever poses as the most important public health problem in Bandar Lampung today. Increasing number of cases has been occurred from 2001 to 2006, when in 2001 incidence rate was 13.56/100.000 and became 109.8/100.00 at 2006 and at the end of February 2007 it was stated that Bandar Lampung experienced local outbreak dengue hemorrhagic fever. A case-control study was conducted to explore the correlation of suspected risk factors with dengue infection in Bandar Lampung from 20 April to 30 May 2007. 230 cases and 230 controls were included for statistical analysis. After further adjusting of confounders, there are strong correlation between habitual elimination of mosquito breeding sites and use of personal protective (e.g. the use repellent, mosquito coil and use insecticide hand sprayer) with dengue case. Individual has one PSN estimated to be $2,22(95 \% \mathrm{Cl}: 1,32-3,72)$ times as great for individual has 3 PSN and individual did not PSN estimates to be $5,85(95 \% \mathrm{Cl}: 2,86-11,99)$ times as great has dengue fever for individual has 3 PSN after controlled by history neighborhood DHF, water container around house, use of mosquito prevention agent. Community health center staff should conduct epidemiology investigation to eradicate dengue fever by focusing on community empowerment.

Keywords: Dengue, Aedes aegypti, Personal protection

*Staf Pengajar Jurusan Kesehatan Lingkungan Politeknik Kesehatan Tanjung Karang, Jl. Raya Haji Mena No. 100 Km 14, Natar, Bandar lampung (e-mail: amha_kuang@plasa.com) **Staf Pengajar Departemen PKIP Fakutas Kesehatan Masyarakat Universitas Indonesia, Gd. D Lt. 1 Fakultas Kesehatan Masyarakat Universitas Indonesia, Kampus Baru UI Depok 16424 (e-mail: dian_ayubi@yahoo.com) 
Salah satu masalah kesehatan masyarakat yang serius adalah penyakit demam berdarah dengue (DBD). Data WHO (2000) menunjukkan diperkirakan sebanyak 2,5 sampai 3 (tiga) milyar penduduk dunia berisiko terinfeksi virus dengue dan setiap tahunnya terdapat 50-100 juta penduduk dunia terinfeksi virus dengue, 500 ribu diantaranya membutuhkan perawatan intensif di fasilitas pelayanan kesehatan. Setiap tahun dilaporkan sebanyak 21.000 anak meninggal karena DBD atau setiap 20 menit terdapat satu orang anak yang meninggal. ${ }^{1}$ Departemen Kesehatan Republik Indonesia mencatat bahwa terjadi peningkatan jumlah penderita dari tahun ke tahun. Di Indonesia, tahun 2002 incidence rate tercatat sebesar 19,2/100.000 penduduk, tahun 2003 meningkat menjadi 24,3/100.000, tahun 2004 menjadi 37,0/100.000 penduduk dan pada tahun 2005 meningkat menjadi 38,1/100.00 penduduk. ${ }^{2}$

Kota Bandar Lampung merupakan salah satu daerah endemis DBD di Propinsi Lampung. Peningkatan insiden DBD juga terjadi dari tahun ke tahun. Jika pada tahun 2001 incidence rate DBD sebesar 13,56 per 100.000 penduduk, tahun 2005 meningkat menjadi 50,1 per 100.000 penduduk dan pada tahun 2006 meningkat 110,2/100.000 penduduk, hingga akhir Maret 2007 jumlah kasus DBD di Kota Bandar Lampung telah melebihi 1.000 kasus, sehingga Pemerintah Kota Bandar Lampung menetapkan sebagai KLB lokal. ${ }^{3}$ Dilihat dari endemisitas daerah, dari 13 kecamatan yang ada, semua kecamatan di Kota Bandar Lampung merupakan daerah endemis DBD, dan dari 98 kelurahan yang ada, 50\% lebih merupakan kelurahan endemis DBD. Tahun 2003 terdapat 28 kelurahan kemudian meningkat menjadi 34 kelurahan pada tahun 2004, kemudian meningkat lagi menjadi 54 kelurahan pada tahun 2006. ${ }^{3}$

Peningkatan jumlah kasus DBD di Kota Bandar Lampung diduga kuat berkaitan dengan faktor perilaku individu dalam melaksanakan PSN (menguras, menutup dan mengubur) hal ini dapat dilihat dengan masih rendahnya angka bebas jentik di Kota Bandar Lampung dari tahun-ketahun masih berada dibawah $80 \%$. Faktor lainnnya seperti kebiasaan mencegah gigitan nyamuk dan faktor lingkungan disekitar rumah seperti keberadaan benda yang dapat menampung air disekitar rumah yang merupakan tempat perindukan nyamuk dan pemasangan kawat kassa pada ventilasi rumah juga berkontribusi terhadap penigkatan kasus DBD di Bandar Lampung.

Penelitian ini bertujuan untuk mengetahui faktor kebiasaan melaksanakan PSN dengan $3 \mathrm{M}$ (Menguras, Menutup dan Mengubur) dengan kasus DBD di Kota Bandar Lampung. Selain itu, penelitian ini ingin menganalisis peran faktor risiko lain (kovariat) yaitu perilaku pencegahan gigitan nyamuk, karakteristik individu (umur, jenis kelamin, pekerjaan), riwayat penderita disekitar rumah sebelumnya, dan keberadaan barang yang dapat menampung air di sekitar rumah yang berpengaruh.

\section{Metode}

Penelitian yang menggunakan desain kasus-kontrol ini mempunyai populasi yaitu seluruh penduduk kota Bandar Lampung yang berdomisili di Kota Bandar Lampung minimal 1(satu) bulan sebelum penelitian dilaksanakan. Sampel adalah penduduk kota Bandar Lampung yang berdomisili di Kota Bandar Lampung minimal 1(satu) bulan sebelum penelitian dilaksanakan, penduduk yang menderita penyakit Demam Berdarah Dengue sebagai kasus dan penduduk yang tidak menderita penyakit Demam Berdarah Dengue dijadikan sebagai kontrol. Kontrol eligible adalah semua penduduk kota Bandar Lampung yang berusia sama dengan usia kasus (jika kasus atau kontrol berusia $<10$ tahun (belum dewasa), wawancara dilakukan pada orang tua (ibu) responden. Jumlah sampel dalam penelitian ini sebesar 406 orang yang terdiri dari 203 kasus dan 203 kontrol. Pengumpulan data dilakukan melalui wawancara menggunakan kuesioner tertutup dan observasi menggunakan check-list pada kasus dan kontrol untuk memperoleh informasi tentang variabel yang diteliti. Penelitian ini dilaksanakan dari bulan 20 April 2007 sampai dengan 31 Mei 2007. Analisis stratifikasi dilakukan dengan tujuan pengontrolan terhadap variabel kovariat dari kemungkinan adanya potensial interaksi antar variabel faktor risiko atau adanya faktor perancu dari masing-masing kovariat terhadap faktor risiko utama penelitian. Analisis multivariat digunakan untuk melihat hubungan asosiasi antara faktor risiko utama dari pengaruh beberapa faktor risiko lain (kovariat) dalam hubungannya dengan kejadian Demam Berdarah Dengue. Analisis multivariat akan dilakukan dengan menggunakan analisis unconditional logistic regression (untuk analisis data kasus kontrol tidak berpadanan).

\section{Hasil}

Berbagai variabel yang diamati terlihat terdistribusi berbeda pada kelompok kasus dan kontrol. Hal tersebut mengindikasikan bahwa variabel tersebut memenuhi kriteria variabel perancu. (Lihat Tabel 1)

Semua variabel yang diteliti mempunyai nilai $\mathrm{p} \mathrm{ku-}$ rang dari 0.25 , sehingga memenuhi syarat sebagai variabel kandidat untuk analisis multivariat. (Lihat Tabel 2)

Variabel riwayat tetangga yang sakit DBD dan keberadaan tempat penampung air di sekitar rumah serta kebiasaan melakukan pencegahan gigitan nyamuk merupakan faktor perancu terhadap hubungan variabel kebiasaan melakukan PSN dengan kejadian DBD (lihat tabel 3).

Terlihat bahwa kebiasaan melakukan PSN berhubungan dengan kejadian DBD, individu yang tidak melakukan 3 M berisiko 5,85 (95\% CI : 2,86-11,99) kali lebih besar untuk terkena DBD daripada individu yang melakukan $2 \mathrm{M}$ atau $3 \mathrm{M}$. Setelah pengendalian variabel 
Tabel 1. Distribusi Kelompok Kasus dan Kelompok Kontrol Berdasarkan Berbagai Karakteristik

\begin{tabular}{|c|c|c|c|c|c|}
\hline \multirow[t]{2}{*}{ Karakteristik } & \multirow[t]{2}{*}{ Katagori } & \multicolumn{2}{|c|}{ Kontrol } & \multicolumn{2}{|c|}{ Kasus } \\
\hline & & $n=203$ & $\%$ & $\mathrm{n}=\mathbf{2 0 3}$ & $\%$ \\
\hline \multirow[t]{2}{*}{ Jenis Kelamin } & Perempuan & 98 & 48,28 & 137 & 67,49 \\
\hline & Laki-laki & 105 & 51,72 & 66 & 32,51 \\
\hline \multirow[t]{3}{*}{ Umur } & $0-14$ tahun & 3 & 1,48 & 15 & 7,39 \\
\hline & $15-49$ tahun & 106 & 52,22 & 157 & 77,34 \\
\hline & $>50$ tahun & 94 & 46,31 & 31 & 15,27 \\
\hline \multirow[t]{2}{*}{ Pekerjaan } & Tidak Berisiko & 39 & 19,21 & 66 & 32,51 \\
\hline & Berisiko & 164 & 80,79 & 137 & 67,49 \\
\hline \multirow[t]{2}{*}{ Riwayat DBD Tetangga } & Tidak Ada & 105 & 51,72 & 51 & 25,12 \\
\hline & Ada & 98 & 48,28 & 152 & 74,88 \\
\hline \multirow[t]{2}{*}{ Penampung anair } & Tidak ada & 101 & 49,75 & 149 & 73,40 \\
\hline & Ada & 102 & 50,25 & 54 & 26,60 \\
\hline \multirow[t]{2}{*}{ Menguras } & Ya & 155 & 76,35 & 107 & 52,71 \\
\hline & Tidak & 48 & 23,65 & 96 & 47,29 \\
\hline \multirow[t]{2}{*}{ Menutup } & Ya & 124 & 61,08 & 66 & 32,51 \\
\hline & Tidak & 79 & 38,92 & 137 & 67,49 \\
\hline \multirow[t]{2}{*}{ Mengubur } & Ya & 60 & 29,56 & 33 & 16,26 \\
\hline & Tidak & 143 & 70,44 & 170 & 83,74 \\
\hline \multirow[t]{2}{*}{ Anti nyamuk bakar } & Melakukan & 76 & 37,44 & 48 & 23,65 \\
\hline & Tidak Melakukan & 127 & 62,56 & 155 & 76,35 \\
\hline \multirow[t]{2}{*}{ Anti nyamuk Semprot } & Melakukan & 102 & 50,25 & 32 & 15,76 \\
\hline & Tidak Melakukan & 101 & 49,75 & 171 & 84,24 \\
\hline \multirow[t]{2}{*}{ Repellent } & Melakukan & 158 & 77,83 & 97 & 47,78 \\
\hline & Tak Melakukan & 45 & 22,17 & 106 & 52,22 \\
\hline \multirow[t]{3}{*}{ Mencegah Gigitan } & Melakukan 2 \&3 Pencegahan & 44 & 21,67 & 127 & 62,56 \\
\hline & Melakukan 1 Pencegahan & 75 & 36,95 & 45 & 22,17 \\
\hline & Tidak Melakukan Pencegahan & 84 & 41,38 & 31 & 15,27 \\
\hline \multirow[t]{3}{*}{ Melakukan PSN } & Melakukan 2 dan $3 \mathrm{M}$ & 65 & 32,02 & 129 & 63,55 \\
\hline & Melakukan $1 \mathrm{M}$ & 71 & 34,98 & 60 & 29,56 \\
\hline & Tidak Melakukan $3 \mathrm{M}$ & 67 & 33,00 & 14 & 6,90 \\
\hline
\end{tabular}

Tabel 2. Hasil Analisis Bivariat Nilai Hubungan antara Variabel Dependen dengan DBD, di Kota Bandar Lampung Tahun 2007

\begin{tabular}{|c|c|c|c|c|}
\hline Perilaku & Katagori & OR (Crude) & $95 \%$ CI OR & nilai $\mathrm{p}$ \\
\hline \multirow[t]{3}{*}{ Melakukan PSN } & Melakukan 2 dan $3 \mathrm{M}$ & 1,00 & Reference & \\
\hline & Melakukan $1 \mathrm{M}$ & 2,35 & $1,45-3,80$ & 0,01 \\
\hline & Tidak Melakukan $3 \mathrm{M}$ & 9,51 & $4,80-19,56$ & 0,01 \\
\hline \multicolumn{5}{|l|}{ Kovariat } \\
\hline \multirow[t]{3}{*}{ Pencegahan Gigitan Nyamuk } & Melakukan 2 dan 3 Pencegahan & 1,00 & Reference & \\
\hline & Melakukan 1 Pencegahan & 4,81 & $2,82-8,22$ & 0,01 \\
\hline & Tidak Melakukan Pencegahan & 6,04 & $3,81-9,60$ & 0,01 \\
\hline \multirow[t]{2}{*}{ Jenis Kelamin } & Perempuan & 1,00 & Reference & \\
\hline & Laki-laki & 2,22 & $1,46-3,40$ & 0,01 \\
\hline \multirow[t]{3}{*}{ Umur } & $\geq 45$ tahun & 1,00 & Reference & \\
\hline & $15-44$ tahun & 0,32 & $0,20-0,50$ & 0,01 \\
\hline & $0-14$ tahun & 4,78 & $2,92-7,93$ & 0,01 \\
\hline \multirow[t]{2}{*}{ Pekerjaan } & Tidak Berisiko & 1 & Reference & \\
\hline & Berisiko & 2,03 & $1,25-3,29$ & 0,01 \\
\hline \multirow{2}{*}{ Riwayat DBD Tetangga } & Tidak Ada & 1,00 & Reference & \\
\hline & Ada & 3,19 & $2,06-4,97$ & 0,01 \\
\hline \multirow[t]{2}{*}{ Kontainer * } & Tidak Ada & 1,00 & Reference & \\
\hline & Ada & 2,79 & $1,80-4,31$ & 0,01 \\
\hline
\end{tabular}

*)Keberadaan benda yang dapat menampung air di sekitar rumah 
Tabel 3. Penilaian Faktor Perancu Kebiasaan PSN dengan Kejadian DBD di Kota Bandar Lampung Tahun 2007

\begin{tabular}{|c|c|c|c|c|c|}
\hline Confounder yang dikeluarkan & $\begin{array}{c}\text { OR Crude } \\
\text { (Full Model) }\end{array}$ & $\begin{array}{c}\text { OR Reduce } \\
\text { Model }\end{array}$ & Delta OR & $\begin{array}{c}\text { Delta OR } \\
(\%)\end{array}$ & Simpulan \\
\hline \multicolumn{6}{|l|}{ Melakukan 1 M } \\
\hline Sex & 2,12 & 2,045 & 0,07 & 3,29 & Konfounding - \\
\hline Umur & 2,12 & 2,109 & 0,01 & 0,27 & Konfounding - \\
\hline Pekerjaan & 2,12 & 2,109 & 0,01 & 0,27 & Konfounding - \\
\hline Tetangga & 2,12 & 2,095 & 0,02 & 0,96 & Konfounding - \\
\hline Kontainer & 2,12 & 1,948 & 0,17 & 7,88 & Konfounding - \\
\hline Cegah & 2,12 & 2,363 & 0,25 & 11,82 & Konfounding + \\
\hline \multicolumn{6}{|l|}{ Tidak melakukan $3 \mathrm{M}$} \\
\hline Sex & 6,51 & 6,109 & 0,40 & 6,16 & Konfounding - \\
\hline Umur & 6,51 & 6,457 & 0,05 & 0,82 & Konfounding - \\
\hline Pekerjaan & 6,51 & 6,457 & 0,05 & 0,82 & Konfounding - \\
\hline Tetangga & 6,51 & 7,334 & 0,82 & 12,60 & Konfounding + \\
\hline Kontainer & 6,51 & 7,199 & 0,69 & 10,60 & Konfounding + \\
\hline Cegah & 6,51 & 8,045 & 1,54 & 23,66 & Konfounding + \\
\hline
\end{tabular}

Tabel 4. Model Akhir Regresi Logistik Ganda PSN dan DBD di Kota Bandar Lampung Tahun 2007

\begin{tabular}{lccccc}
\hline Variabel dalam model & Coef. & Std. Err. & P>lz| & OR & [95\% CI] \\
\hline Kebiasaan melakukan PSN & & & & & Reference \\
Melakukan 2 M atau 3 M & & & & $\mathbf{1}$ & $1,32-3,72$ \\
Melakukan 1 M & 0,80 & 0,26 & 0,01 & $\mathbf{2 , 2 2}$ & $2,86-11,99$ \\
Tidak melakukan 3 M & 1,77 & 0,37 & 0,01 & $\mathbf{5 , 8 5}$ & $1,69-4,56$ \\
Riwayat DBD tetangga & 1,02 & 0,25 & 0,01 & $\mathbf{2 , 7 8}$ & $1,52-4,12$ \\
Kontainer & 0,92 & 0,25 & 0,01 & $\mathbf{2 , 5 0}$ & $2,18-6,58$ \\
Pencegahan gigitan nyamuk & & & & & $3,67-12,04$ \\
Melakukan 1 pencegahan & 1,33 & 0,28 & 0,01 & $\mathbf{3 , 7 9}$ & $\mathbf{6 , 6 5}$ \\
Tidak melakukan pencegahan & 1,89 & 0,30 & 0,01 & & \\
$\quad$ cons & 2,23 & 0,27 & & & \\
\hline
\end{tabular}

riwayat tetangga yang pernah sakit DBD dan keberadaan benda yang dapat menampung air di sekitar rumah dan kebiasaan melakukan pencegahan gigitan nyamuk. (Lihat Tabel 4)

\section{Pembahasan}

Setelah dikontrol dengan variabel perancu, penelitian ini menemukan bahwa individu yang tidak melakukan 3 $\mathrm{M}$ berisiko 5,85 kali lebih besar untuk terkena demam berdarah dengue daripada individu dengan kebiasaan melakukan $2 \mathrm{M}$ atau $3 \mathrm{M}$, Hasil penelitian ini sesuai dengan penelitian sebelumnya bahwa perilaku pemberantasan jentik yang buruk berisiko 8,13 kali lebih besar untuk terkena DBD. ${ }^{4,5}$ Pencegahan dan pengendalian DBD tergantung pada pengendalian vektor penular Ae.aegyp$t i$ yang terdapat disekeliling rumah tempat sebagian besar penularan terjadi. ${ }^{6}$ Peneliti lain menyatakan penularan DBD tergantung pada kebiasaan menyimpan air yang menjadi tempat berkembang biak Ae.aegypti yang berada di sekeliling rumah. ${ }^{7}$ Kelompok penelitian lain menyatakan bahwa, perilaku pemberantasan jentik akan berpengaruh kepada kepadatan jentik yang akhirnya menurunkan DBD. 8

Partisipasi indidividu yang rendah dalam melakukan PSN terjadi karena mereka belum mengerti dan menyadari pentingnya PSN, sehingga bersikap masa bodoh (tidak peduli) dengan anjuran dan ajakan pemerintah dalam melakukan kegiatan PSN. Membatasi keberadaan tempat berkembang biak Ae.aegypti, akan membantu mengurangi kepadatan nyamuk yang berdampak pada kemungkinan berkurangnya penularan penyakit.

Pengendalian DBD melalui PSN hanya mungkin dilakukan melalui gerakan masyarakat, yang tidak mungkin berwujud tanpa peningkatan pengetahuan dan perubahan perilaku. Keberhasilan beberapa negara mengendalikan DBD dicapai melakukan perubahan perilaku mayarakat yang sinambung dengan metode COM$B I .{ }^{9}$ Melalui pertemuan bulanan rutin untuk membuat 
rencana kegiatan pengendalian DBD dapat menurunkan secara tajam angka Container Index, House Index dan Breteau Index. ${ }^{10}$ Program pengendalian vektor yang dijalankan Dinas Kesehatan Kota Bandar Lampung melalui pengasapan, abatisasi selektif, PSN dan PJB, tidak terlihat berhubungan dengan keberadaan jentik Ae.aegypti di rumah tangga, karena mutu program yang rendah, tenaga lapangan yang minim serta tanpa perubahan perilaku pengendalian jentik nyamuk dalam masyarakat. ${ }^{9}$ Masyarakat tidak merasa terbebani akibat biaya perawatan gratis, bahkan mereka cenderung menyalahkan pemerintah yang terlambat melaksanakan fogging. Masyarakat benar-benar tidak memahami bahwa partisipasi mereka pada pembersihan sarang nyamuk berkontribusi sangat besar terhadap pengendalian DBD. ${ }^{11}$

Kasus demam berdarah dengue di Kota Bandar Lampung yang tinggi dipengaruhi oleh partisipasi masyarakat yang rendah. Temuan ini merupakan dukungan terhadap peneliti terdahulu yang membuktikan bahwa dengan melakukan PSN dengan $3 \mathrm{M}$ (menguras, menutup tempat penampungan air dan mengubur barang bekas yang tidak dipergunakan lagi) akan menurunkan populasi nyamuk Ae.aegypti yang merupakan vektor penyakit demam berdarah dengue di kota Bandar Lampung. Apabila masyarakat bersedia menjaga kondisi tempat tinggal mereka terutama mencegah berkembang biak nyamuk Ae.aegypti di lingkungan rumah, maka rantai penularan DBD akan terputus yang pada gilirannya menurunkan angka kesakitan demam berdarah dengue. Perilaku masyarakat juga selalu dihubungkan dengan keseriusan penyakit dan berdampak kepada upaya mencari kebiasaan yang mendukung pencegahan penyakit. Bila upaya PSN telah menjadi kebutuhan dan berakar pada kehidupan masyarakat di suatu daerah atau wilayah, maka akan terjadil perilaku sehat yang mendukung mengatasi dan meniadakan tempat perindukan nyamuk disekitar rumah tinggal. Hal tersebut menyatakan bahwa penerapan strategi COMBI membutuhkan sumber daya yang besar, sehingga tidak tepat diterapkan di Kota Bandar Lampung, untuk itu perlu dicari alternatif lain yang sesuai dengan karakteristik daerah yang bersifat lokal spesifik. ${ }^{12}$

\section{Kesimpulan}

Penelitian ini menemukan hubungan yang bermakna antara kebiasaan melakukan PSN dengan kejadian demam berdarah dengue di Kota Bandar Lampung. Individu yang yang tidak melakukan dan melakukan $1 \mathrm{M}$ (menguras atau menutup atau mengubur saja) berisiko 2,22 dan 5,85 kali lebih besar untuk menderita DBD daripada yang melakukan PSN (2 M atau $3 \mathrm{M}$ ).

\section{Saran}

Berdasarkan temuan penelitian ini disarankan pada petugas penyelidikan epidemiologi puskesmas agar melaksanakan ketentuan Departemen Kesehatan sebagai berikut : (a) Bila ditemukan penderita DBD lainnya (satu atau lebih) atau ditemukan 3 atau lebih tersangka DBD dan ditemukan jentik ( $\geq 5 \%$ ) dari rumah/bangunan yang diperiksa maka dilakukan penggerakan masyarakat dalam PSN DBD, larvasida, penyuluhan dan pengasapan dengan insektisida di rumah penderita dan rumah/ bangunan sekitarnya dalam radius 200 meter 2 siklus dengan interval 1 minggu. (b) Bila tidak ditemukan penderita DBD lainnya seperti poin a) di atas tetapi ditemukan jentik maka dilakukan penggerakan masyarakat dalam PSN DBD, larvasida, dan penyuluhan. Bila tidak ditemukan penderita lainnya seperti tersebut di atas dan tidak ditemukan jentik maka dilakukan penyuluhan kepada masyarakat.

\section{Daftar Pustaka}

1. WHO. Climate Change And Human Health - Risk And Responses. 2002 Avalable from: http://www.cdc. gov /ncidod/dvbid/dengue. Access 21 Mei 2006.

2. Depkes RI. Pencegahan dan Pemberantasan Demam Berdarah Dengue di Indonesia. Jakarta. Ditjen P2M. 2005

3. Dinkes Kota Bandar Lampung. Evaluasi Program Pencegahan dan Pemberantasan Penyakit. Dinas Kesehatan. Kota Bandar Lampung. 2007

4. Kasdi, Muhamad. Analisis Faktor Risiko terhadap Kejadian Demam Berdarah DengueDBD di Kota Bontang Tahun 2003. Available from: http://www.litbang.depkes.go.id/maskes/052004/ demamberdarahl.htm. Access 2 Maret 2006.

5. Usman, Sarif. Faktor Risiko Yang Berhubungan Dengan Kejadian Demam Berdarah Dengue di Kota Bandar Lampung Tahun 2002. Tesis FKM-UI. 2002

6. Gubler, Duane J. Dengue and Dengue Hemorrhagic Fever. Clinical Microbiology Reviews, July 1998, p. 480-496, Vol. 11, No. 3

7. Halstead, SB. Selected primary healthcare: strategies for control of disease in the developing world. XI. Dengue. Rev Infect Dis;16:251-64. 1984

8. Win, Than, (et al). Dengue Buletin. Community-based Assessment of Dengue-related Knowledge among Caregivers. India. WHO-SEARO. 2004

9. Yushananta, Prayudhy. Pengendalian Jentik Aedes Aegypti di wilayah Puskesmas Way Halim Kota Bandar Lampung. Tesis FKM-UI. 2006

10. Therawiwat, Manirat; Fungladda, Wijltr; Kawwkungwai, Jaranit; Imamee, Nirat dan Steckler, Allan. Community-Based Approach for Prevention and Control of Dengue Hemorrhagic Fever in Kanchanaburi Province, Thailand. Southeast Asian Journal of Tropical Medicine and Public Health; Nov 2005; 36,6; Health \& Medical Complete hal 1439

11. Kodim, Nasrin. Mencegah dan Mengendalikan Petaka Kesehatan Masyarakat Dengan Siklus Kebijakan Yang Berbasis Evidens Epidemiologi, Pidato pengukuhan, disampaikan pada upacara penerimaan jabatan Guru Besar Tetap dalam Ilmu Epidemiologi pada Fakultas Kesehatan Masyarakat Univeritas Indonesia, Jakarta. 2006

12. Renganathan, E, (et.al). Dengue Buletin. Towards Sustaining Behavioural Impact in Dengue Prevention and Control. India: WHOSEARO. 2003 